\title{
Studi Eksperimen Pengaruh Variasi Kecepatan Putar Kompresor dan Beban Pendinginan pada Sistem Refrigerasi Cascade
}

\author{
Ilman dan Ary Bachtiar Krishna Putra \\ Jurusan Teknik Mesin, Fakultas Teknologi Industri, Institut Teknologi Sepuluh Nopember (ITS) \\ Jl. Arief Rahman Hakim, Surabaya 60111 Indonesia \\ e-mail: ary_bach@me.its.ac.id
}

\begin{abstract}
Abstrak-Peningkatan kebutuhan energi masyarakat mendorong manusia untuk terus meningkatkan kualitas sistem maupun proses yang lebih baik dan hemat energi. Salah satu hasil perkembangan teknologi di zaman sekarang Adalah Sistem Refrigerasi Cascade yang mampu mecapai temperatur jauh di bawah $0^{\circ} \mathrm{C}$. Salah satu aplikasi sistem tersebut adalah sebagai cold storage yang mampu bekerja dengan beban yang berbeda-beda. Hal tersebut menyebabkan adanya pengaruh beban terhadap sistem. Selain itu, kecepatan putar kompresor yang berbeda menjadi salah satu faktor yang mempengaruhi performa sistem, sehingga dilakukan penelitian untuk meningkatkan performa sistem refrigersi cascade dengan memvariasikan kecepatan putar kompresor dan beban pendinginan, sehingga didapatkan kecepatan putar yang sesuai dengan besar beban pendinginan yang diterima oleh sistem cascade. Pengujian Sisem Refrigerasi Cadcase ini menggunakan refrigeran Musicool-22 pada High Stage dan R-407F pada Low Stage, dengan 8 titik pengukuran temperatur dan tekanan. Saat pengukuran dilakukan, sistem diberikan beban pendinginan berupa kalor yang dihasilkan oleh electric heater. Dimana beban tersebut terpasang di dalam kabin sehingga kalor yang dihasilkan oleh electric heater dapat diserap oleh evaporator Low Stage. Beban yang divariasikan dari electric heater tersebut adalah 0 (tanpa beban), 28,8; 86,4; dan 158,4 Watt. Selain itu, frekuensi listrik yang masuk ke kompresor juga divariasikan. Besar frekuensi yang divariasikan yaitu 30, 35, 40, 45, dan $50 \mathrm{~Hz}$. Pengukuran dan pengambilan data dilakukan sebanyak 5 kali. Hasil yang didapatkan dari eksperimen ini yaitu kecepatan putar yang paling sesuai dengan beban yang diberikan terhadap sistem cascade. Pada beban 0 Watt kecepatan putar yang sesuai adalah 1800 rpm dengan COP sebesar 1,397, temperatur kabin senilai $-31,12{ }^{\circ} \mathrm{C}$ dan daya yang dibutuhkan $0,554 \mathrm{~kW}$. Pada beban 28,8 Watt kecepatan putar yang sesuai adalah 1800 rpm dengan COP sebesar 1,405, temperature kabin senilai $29.78^{\circ} \mathrm{C}$ dan daya yang dibutuhkan $0,605 \mathrm{~kW}$. Pada beban 86,4 Watt kecepatan putar yang sesuai adalah $2100 \mathrm{rpm}$ dengan COP sebesar 1,329, temperature kabin senilai $28,88^{\circ} \mathrm{C}$ dan daya yang dibutuhkan $0,564 \mathrm{~kW}$. Sedangkan Pada beban 158,4 Watt kecepatan putar yang sesuai adalah 3000 rpm dengan COP sebesar 0,976, temperatur kabin senilai $-28,1^{\circ} \mathrm{C}$ dan daya yang dibutuhkan $0,722 \mathrm{~kW}$.
\end{abstract}

Kata Kunci-Sistem Refrigerasi; Cascade; COP cascade; kecepatan putar; frekuensi.

\section{PENDAhuluan}

$\mathrm{P}$ ada saat ini peningkatan efisiensi energi menjadi perhatian sekelompok manusia yang berupaya untuk memenuhi kebutuhan hidup yang semakin meningkat dengan konsumsi energi seminimal mungkin serta memiliki kualitas yang lebih baik. Hal ini berlaku untuk di setiap sektor, salah satu sektor adalah sistem pendinginan. Peningkatan di sektor tersebut menyababkan evolusi teknologi pendingin yang semakin canggih. Salah satu perubahan yang baik yang dapat dirasakan adalah sistem pendingin yang dapat mencapai temperatur yang jauh di bawah $0^{\circ} \mathrm{C}$ dengan sistem yang hemat energi.

Salah satu tujuan penggunaan alat pendingin yaitu untuk mencegah pembusukan makanan lebih cepat. Alat pendingin yang sering kita jumpai yaitu cascade atau freezer karena mampu mencapai suhu pendinginan hingga dibawah $0^{\circ} \mathrm{C}$. Sistem ini minimal terdiri dari dua sistem refrigerasi kompresi uap (Vapor Refrigeration System) yang menggunakan 2 kompresor untuk mengalirkan 2 jenis refrigeran yang berbeda. Kalor yang dilepaskan kondensor di sistem temperatur rendah (Low Stage) diserap oleh evaporator dari sistem temperatur tinggi (High Stage) dengan bantuan penukar kalor yang disebut dengan Intermediet. Sistem refrigerasi cascade merupakan cara yang terbaik untuk mendapatkan penghematan daya dan peningkatan performa unjuk kerja (COP). Pada industri besar penghematan daya juga seringkali akan menentukan biaya peralatan ekstra. Selain digunakan dalam bidang pengawetan makanan, sistem refrigerasi cascade umumnya diaplikasikan juga untuk bidang-bidang seperti biomedis, farmasi, kimia, blast freezing, pencairan gas, penerbangan (aeronautics) dan lain-lain. Dengan meningkatnya penggunaan freezer di masyarakat, tentu membuat masyarakat berpikir untuk mendapatkan kinerja freezer yang lebih hemat energi dan ramah lingkungan, dengan mengacu pada nilai ODP (ozone depletion potential) dan GWP (global warming potential) dari refrigeran yang digunakan pada freezer.

Pada Penelitian Ruben (2015) [1] mengenai Sistem Refrigerasi Cascade menggunakan refrigeran hidrokarbon Musicool-22 pada High Stage, R-407F pada Low Stage dan intermediate yang digunakan adalah jenis PHE (Plate Heat Exchanger) dengan memvariasikan beban pendinginan pada evaporator di low stage. Namun dalam penelitian tersebut didapatkan COP terendah pada beban terendah, hal ini dikarenakan kompresor pada sistem memiliki daya minimum yang digunakan, sehingga pemberian beban yang terlalu kecil menimbulkan perbedaan beban pendinginan dan daya minimum kompresor yang sangat signifikan sehingga didapatkan penurunan COP yang besar pula.

Oleh sebab itu, salah satu cara untuk mendapatkan performansi yang maksimal adalah melakukan variasi perubahan kecepatan putar kompresor, hal ini berdampak 
pada perubahan daya kompresor, sehingga laju aliran refrigeran yang dialirkan sesuai dengan kebutuhan pendinginan beban yang diberikan.

Untuk mengubah putaran kompresor ini dapat dilakukan dengan cara menambahkan inverter sebagai pengubah frekuensi listrik pada kompresor. Dengan pemberikan variasi putaran kompresor maka laju aliran refrigeran yang mengalir pada sistem juga akan bervariasi. Dengan perubahan tersebut maka kita bisa mengetahui frekuensi yang sesuai dengan besaran beban pendinginan yang dibebankan pada sistem.

\section{URAIAN PENELITIAN}

\section{A. Sistem Refrigerasi}

Sistem refrigerasi adalah sistem yang banyak digunakan untuk mendinginkan suatu produk sesuai yang diharapkan. Salah satu jenis dari sitem refrigerasi adalah Sistem Refrigerasi Kompresi Uap (Compression Vapor Refrigeration System) dimana sistem tersebut menggunakan empat komponen utama yaitu kompresor, kondensor, alat ekspansi dan evaporator.

Kompresor merupakan jantung dari sistem refrigerasi yang mengkompresikan refrigeran berfasa gas yang ada di dalam sistem serta meningkatkan tekanan. Secara ideal proses kompresi akan terjadi secara isentropis dimana tidak ada perubahan nilai entropi, namun aktualnya nilai entropi akan berubah. Setelah dikompresi refrigeran akan mengalir ke kondensor, dimana terjadi pelepasan kalor dari sistem ke lingkungan (surrounded) secara isobaris disertai dengan perubahan fasa dari gas menjadi cair jenuh (saturated liquid) namun secara aktual refrigeran akan mengalami penurunan tekanan sampai dengan keluar kondensor yang mengakibatkan fasa berada pada daerah cair lanjut (subcooled). Setelah itu, refrigeran akan mengalir melewati alat ekspansi yang berfungsi sebagai alat penurun tekanan dimana pada alat ekpansi terjadi flashing effect atau penurunn tekanan secara cepat yang disertai dengan penurunan temperatur tanpa ada perubahan nilai entalpi. Komponen terakhir yang dilalui refrigeran adalah evaporator yang merupakan Heat Excanger yang berfungsi menyerap kalor dari produk atau beban yang didinginkan sehingga terjadi proses evaporasi secara isobaris dan refrigeran akan menguap secara perlahan sampai dengan saturated vapor namun aktualnya, refrigeran akan berubah fasa menjadi superheated vapor yang disebabkan oleh penurunan tekanan selama proses evaporasi. Keempat komponen tersebut dihubungkan dengan sistem perpipaan sehingga sistem dapat bekerja pada siklus yang berlanjut (cycling). [2]

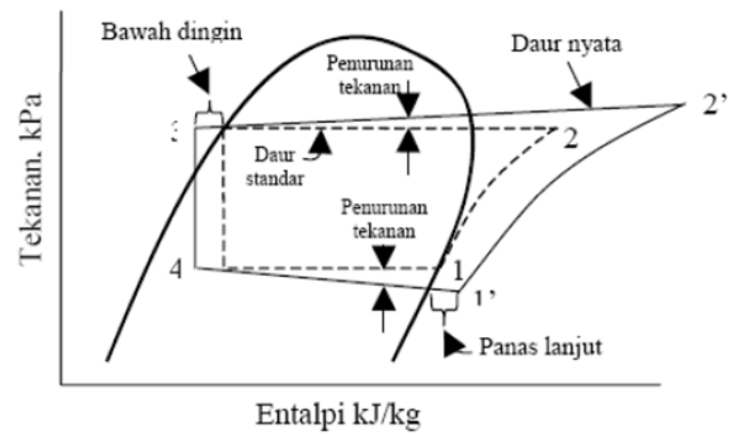

Gambar 1. Skema Perbedaan Sikulis Refrigerasi Ideal dan Aktual

\section{B. Sistem Refrigerasi Cascade}

Sistem Refrigerasi Cascade merupakan suatu sistem refrigerasi yang terbentuk dari gabungan dua Sistem Refrigerasi Kompresi Uap (Vapor Compression Refrigeration System) sehingga pada sistem ini memiliki dua komponen atau double component untuk setiap komponen utamanya. Sistem ini dibuat guna mencapai temperatur evaporator yang sangat rendah (jauh di bawah $0^{\circ} \mathrm{C}$ ). Selain itu sistem ini menggunakan suatu alat yang memisahkan kedua Sistem Refrigerasi Kompresi Uap yang disebut dengan Intermediate yang berfungsi sebagai media atau alat penukar kalor antar evaporator High Stage dengan kondensor Low Stage.

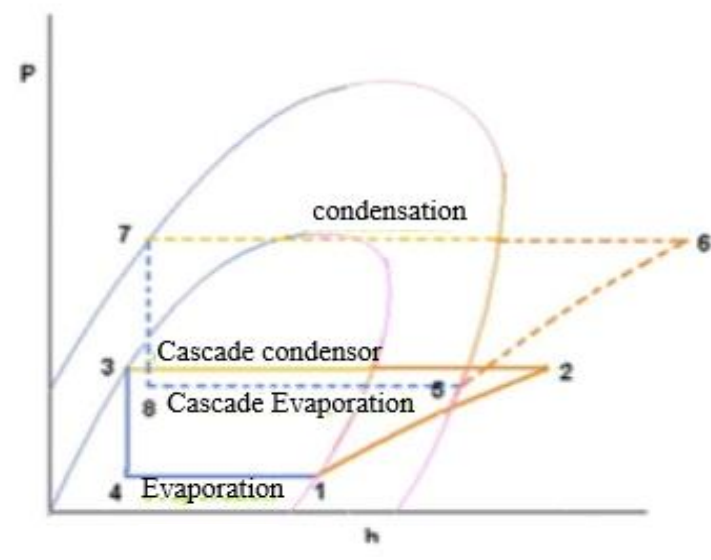

Gambar 2. Skema diagram P-h Sistem Refriegrasi Cascade

Gambar di atas merupakan ilustrasi jika Sistem Refrigerasi Cascade dianalisis dalam satu diagram P-h (kenyataannya tidak bisa). Dari gambar diagram P-h di atas dapat diketahui bahwa sistem refrigerasi tersebut merupakan gabungan dari dua sistem refrigerasi kompresi uap. 1-2- 3-4 merupakan sistem refrigerasi Low Stage sementara 5-6-7-8 merupakan sistem refrigerasi High Stage. Dalam analisis secara aktualnya, diagram P$\mathrm{h}$ yang digunakan pada kedua sistem berbeda sesuai dengan refrigeran yang digunakan.

\section{Persamaan Yang Digunakan Pada Sistem Refrigerasi}

Untuk mendapatkan performa dari sistem refrigerasi cascade maka perlu dilakukan perhitungan dalam pengolahan data dengan penggunakan persamaan sebagai berikut: [3],[4]

1) Laju aliran massa

$$
\begin{aligned}
& \dot{m}_{r e f_{-} H S}=\rho x v \\
& \dot{m}_{\boldsymbol{L S}}=\frac{\dot{m}_{\boldsymbol{H} S}\left(\boldsymbol{h}_{\mathbf{5}}-\boldsymbol{h}_{\mathbf{8}}\right)}{\left(\boldsymbol{h}_{\mathbf{2}}-\boldsymbol{h}_{\mathbf{3}}\right)}\left[\frac{\mathrm{kg}}{\mathrm{s}}\right]
\end{aligned}
$$

2) Kerja kompresi $H S$ dan $L S$

$$
\begin{aligned}
& \text { Wref_HS }=m \text { ref_HS }(h 6-h 5) \\
& \text { Wref_LS }=\text { miref_LS }(h 2-h 1)
\end{aligned}
$$

3) Konsumsi listrik kompresor

$$
\begin{aligned}
& \dot{W i n_{H S}}=V_{H S} \times l_{H S} \times \cos \varphi \\
& \dot{W} n_{L S}=V_{L S} \times l_{L S} \times \cos \varphi
\end{aligned}
$$

4) $Q$ Kondensor High Stage

$$
\dot{Q}_{c}=\dot{m}_{H S} \times\left(h_{6}-h_{7}\right)
$$

5) $Q$ Evap Low Stage

$$
\dot{Q}_{\text {evap }}=\dot{m}_{L S} \times\left(h_{1}-h_{4}\right)
$$


6) COP Thermodinamik

$$
C O P_{\text {Thermodinamic }}=\frac{\dot{Q}_{\text {evap } L S}}{\text { Wref_HS+Wref_LS }}
$$

7) COP Electrical

$$
C O P_{\text {Electrical }}=\frac{\dot{Q}_{\text {evap } L S}}{\text { Wref_-HS }+ \text { Wref_LS }}
$$

8) Heat Rejection Ratio

$$
H R R=\frac{\dot{Q}_{\text {cond_HS }}}{\dot{Q}_{\text {evap_LS }} L} \times 100 \%
$$

\section{MEtodoloGI}

\section{A. Skema Titik Pengukuran}

Pengukuran tekanan dan temperatur Sistem Refrigerasi Cascade ini dilakukan dengan menggunakan pressure gauge dan thermocouple yang terpasang di setiap titiktitik pengukuran yang telah ditentukan sebelumnya. Berikut adalah gambar skema sistem dengan 8 titik pengukuran temperatur dan tekanan.

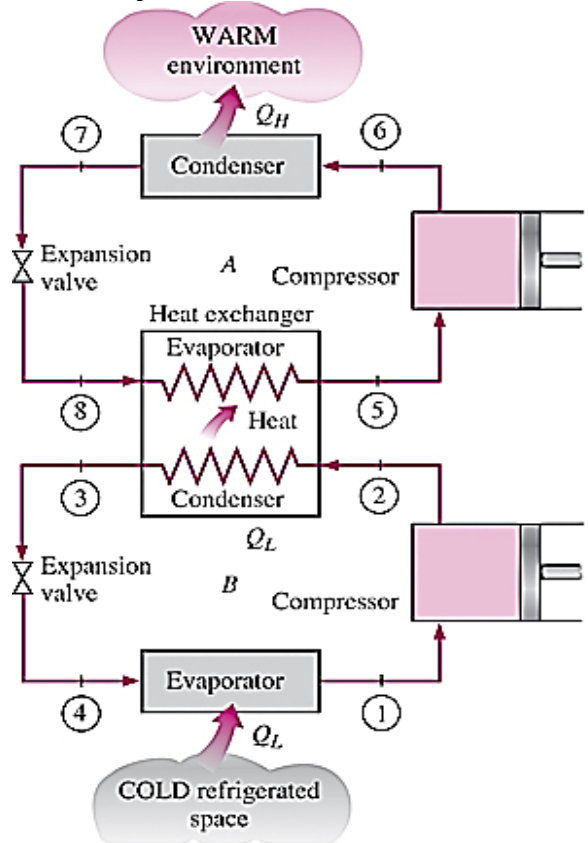

Gambar 3. Skema titik Pengukuran Sistem Refrigerasi cascade

Katerangan:

1 = keluar evaporator low stage

2 = keluar kompresor low stage

3 = keluar kondensor low stage

4 = masuk evaporator low stage

$5=$ keluar evaporator high stage

$6=$ keluar kompresor high stage

$7=$ keluar kondensor high stage

$8=$ masuk evaporator high stage

\section{B. Persiapan}

Tahap pertama yang dilakukan adalah menyiapkan Sistem Refrigerasi Cascade baik dari segi mekanik atau pun elektrik. Hal tersebut dilakukan dengan memastikan rangkaian listrik terpasang dengan baik dan dipastikan tidak ada kebocoran pada sistem.

\section{Pengujian}

Proses pengujian Sistem Refrigerasi Cascade ini dilakukan dengan kecepatan fan kondensor High Stage maksimal serta dengan perubahan Voltase heater sebesar 0, 120, 180, dan 220 Volt yang dihasilkan oleh electric heater di dalam kabin dengan cara mengatur voltage regulator. Selain itu, frekuensi listrik yang masuk ke kompresor juga divariasikan. Besar frekuensi yang divariasikan yaitu 30, 35,40,45, dan $50 \mathrm{~Hz}$ menggunakan Inverter. Pengambilan data dilakukan sebanyak 5 kali di setiap nilai beban yang berbeda dan frekuensi yang berbeda dengan range waktu pengambilan data selama 5 menit.

\section{HASIL PENELITIAN}

\section{A. Analisa Unjuk Kerja Sistem Refrigerasi Cascade}

Berikut adalah analisa hasil perfoorma dari Sistem Refrigerasi Cascade yang telah dilakukan.

1) Temperatur Evaporator LS dan Kabin

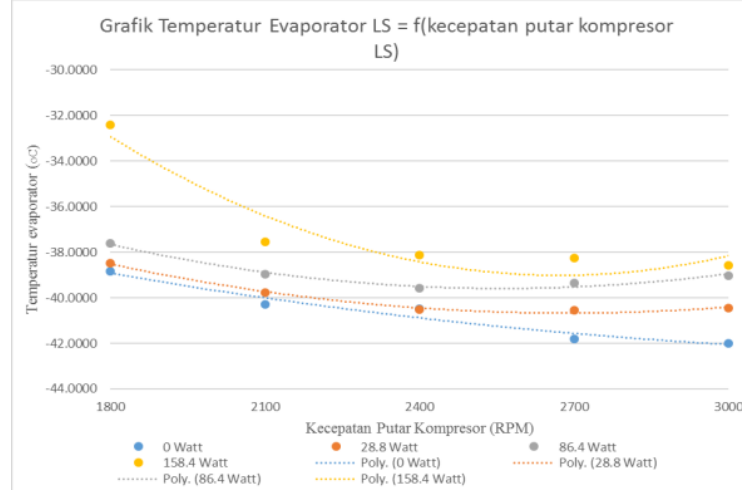

Gambar 4. Grafik Temperatur Evaporator LS = f (Kecepatan Putar Kompressor LS)

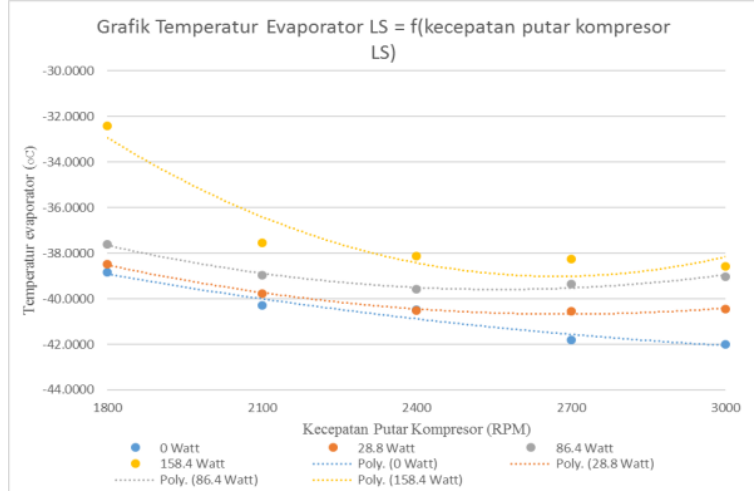

Gambar 5. Grafik Temperatur Kabin $=\mathrm{f}($ Kecepatan Putar Kompressor LS)

Gambar di atas merupakan gambar grafik hubungan antara temperatur evaporator LS dan kabin dengan memvariasikan kecepatan putar kompresor LS serta beban pendinginan yang diberikan oleh electric heater. Dari gambar grafik di atas, trend line grafik mengalami penurunan seiring dengan meningkatnya kecepatan putar kompresor dan berkurangnya beban (electric heater) yang terpasang pada kabin (cooling box).

Naiknya tempeartur evaporator Low stage seiring bertambahnya beban heater disebabkan semakin banyak kalor yang masuk melalui evaporator. Hal ini mengakibatkan naiknya temperatur permukaan evaporator yang kemudian berdampak ke ikut naiknya temperatur refrijeran. Sedangkan penjelasan tentang penurunan temperatur evaporator seiring penambahan kecepatan putar kompresor, dikarenakan semakin cepat putaran kompresor maka aliran masa yang masuk ke orifice TXV semakin banyak. Hal ini mengakibatkan pressur drop pada proses ekspansi semakin besar, dan mengakibatkan tekanan refrigeran yang masuk ke evaporator semakin rendah, sehingga temperatur evaporator semakin rendah. Penurunan temperatur evaporator berbanding lurus dengan penurunan 
temperatur kabin, hal ini dikarenakan evaporator diletakkan didalam kabin yang berfungsi untuk menyerap kalor yang ada didalam kabin, semakin dingin temperatur evaporator maka kalor yang diserap didalam kabin akan semakin banyak, sehinga temperatur kabin juga akan semakin dingin.

2) Flowrate $H S \& L S$

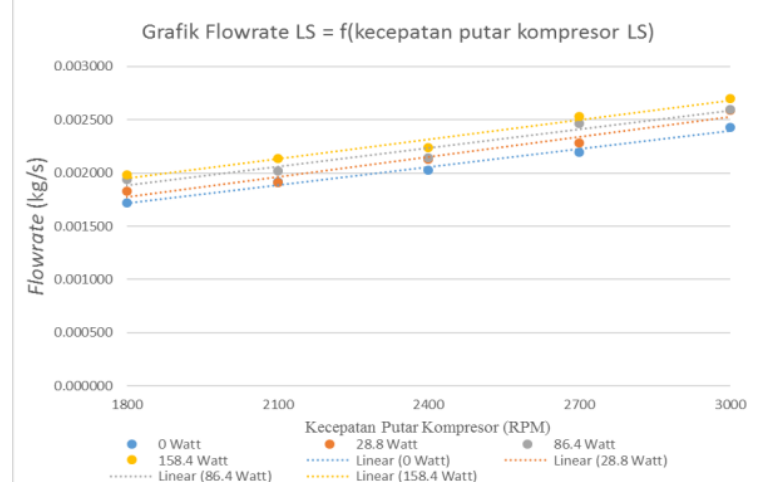

Gambar 6. Grafik Laju Aliran Massa Refrigeran LS = f (Kecepatan Putar Kompressor LS)

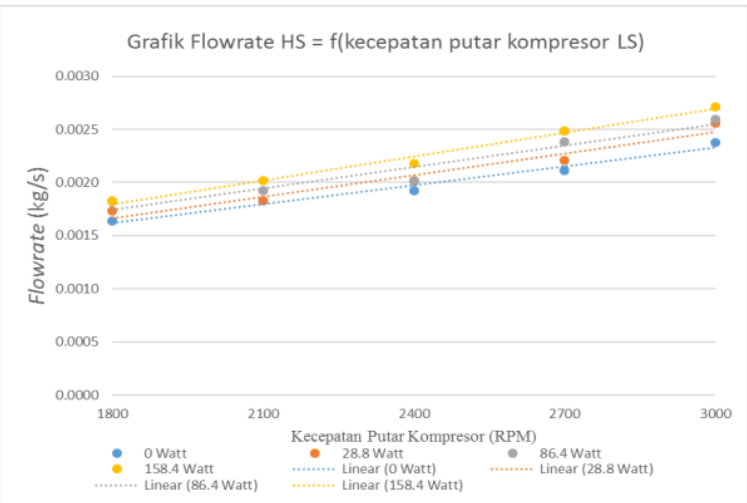

Gambar 7. Grafik Laju Aliran Massa Refrigeran HS = f (Kecepatan Putar Kompressor LS).

Gambar di atas merupakan gambar grafik laju aliran massa refrigeran pada sistem Low stage dan High stage. Dari pengolahan data yang didapatkan pada saat eksperimen, didapatkan bahwa laju aliran massa baik pada High stage atau Low stage terus mengalami peningkatan seiring meningkatnya kecepatan putar kompresor dan bertambahnya beban pendinginan.

Nilai laju aliran massa pada sisi low stage meningkat seiring penambahan beban pendinginan. Hal ini disebabkan karena, Jika beban bertambah maka cairan refrigran di evaporator akan lebih banyak menguap, sehingga besarnya suhu panas lanjut di evaporator akan meningkat. Pada akhir evaporator diletakkan tabung sensor suhu (sensing bulb) dari TXV tersebut. Peningkatan suhu dari evaporator akan menyebabkan uap atau cairan yang terdapat ditabung sensor suhu tersebut akan menguap (terjadi pemuaian) sehingga tekanannya meningkat. Peningkatan tekanan tersebut akan menekan diafragma ke bawah dan membuka katup lebih lebar. Hal ini menyebabkan cairan refrigeran yang berasal dari kondensor akan lebih banyak masuk ke evaporator.

Sedangkan peningkatan laju aliran massa pada sisi LS yang disebabkan peningkatan kecepatan putar kompresor dikarenakan semakin cepat kompresor berputar, maka semakin cepat pula pergerakan piston melakukan kompresi refrigeran, hal ini berdasarkan persamaan perhitungan debit teoritis kompresor torak sebagai berikut:

$$
Q=\frac{\pi}{4} \times d^{2} \times L \times N
$$

Dimana semakin besar nilai kecepatan putar (N) maka semakin besar debit kompresor tersebut. Semakin meningkatnya kecepatan putar kompresor maka tekanan rasio dari kompresor akan meningkat, yang berakibat pula pada penigkatan temperature keluaran kompresor. Sehingga Q_(con-LS) yang merupakan beban pendinginan sisi high stage secara lansung akan meningkan, sehingga laju aliran massa pada sisi high stage pun ikut meningkat.

\section{3) Kerja Kompresi HS dan LS}

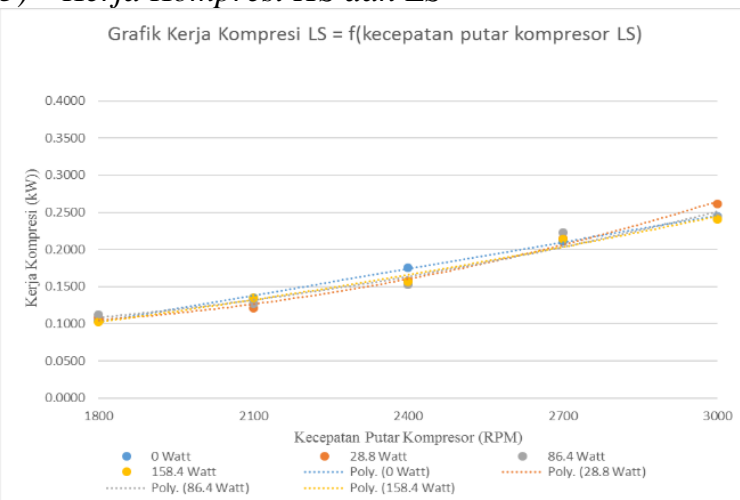

Gambar 8. Grafik Kerja Kompresi LS = f (Kecepatan Putar Kompressor LS)

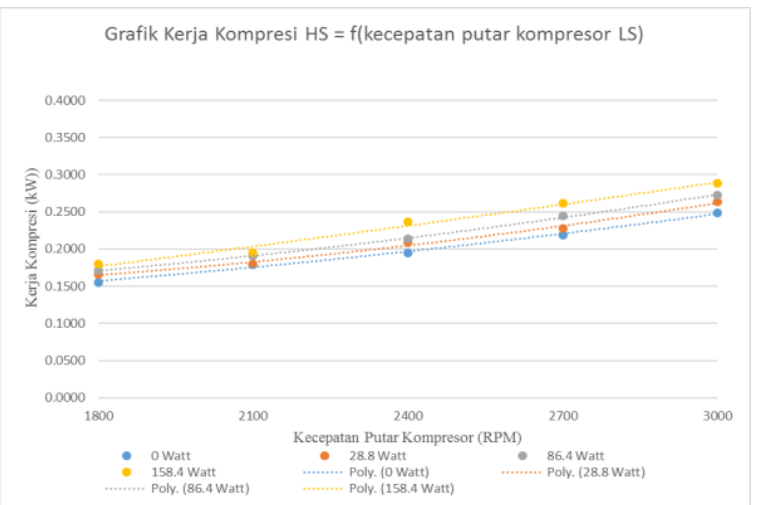

Gambar 9. Grafik Kerja Kompresi HS = f (Kecepatan Putar Kompressor LS)

Gambar di atas menunjukkan bahwa kerja kompresor pada sistem Low stage dan pada sistem High stage terhadap varisi beban pendinginan yang diberikan pada sistem dan kecepatan putar kompresor LS. Grafik tersebut menunjukkan trend line grafik yang naik baik untuk sistem Low stage maupun sistem high stage.

Besarnya nilai dari kerja kompresi dari kedua sistem tersebut dipengaruhi oleh nilai laju aliran massa refrigeran dan alat ekspansi yang digunakan pada masing-masing sistem. Berikut persamaan yang digunakan untuk menghitung nilai kerja kompresi.

Low stage

$$
\begin{array}{ll}
\text { High stage } & \dot{W}_{\text {ref }}=\dot{m}_{\text {ref_LS }}\left(h_{2}-h_{1}\right) \\
& \dot{W}_{\text {ref }}=\dot{m}_{\text {ref_HS }}\left(h_{6}-h_{5}\right)
\end{array}
$$

Dari persamaan diatas dapat dilihat bahwa daya yang dihasilkan kompresor bergantung pada perubahan entalpi keluaran dan masukan kompresor, dan laju massa refrigeran yang melaluinya. Total kerja kompresi merupakan penjumlahan dari kedua kerja kompresi kompresor sisi low stage dan high stage.

Pada gambar 4.3 dan gambar 4.4 dapat dilihat bahwa semakin bertambahnya beban pendinginan dan kecepatan 
putar kompresor menyebabkan bertambahnya laju massa yang melewati evaporator low stage dan high stage. Semakin bertambahnya laju massa pada evaporator menyebabkan semakin bertambahnya laju aliran massa yang akan memasuki kompresor, semakin besar laju massa yang memasuki kompresor maka semakin besar pula kerja yang dibutuhkan kompresor untuk memindahkan refrigeran. Dari teori tersebut maka grafik diatas telah sesuai.

\section{4) Kapasitas Pendinginan}

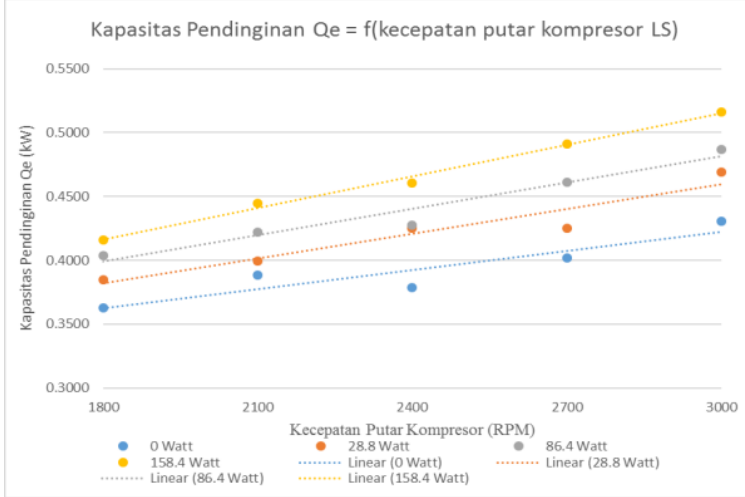

Gambar 10. Grafik Kapasitas Pendinginan = f (Kecepatan Putar Kompressor LS).

Gambar di atas menunjukkan grafik kapasitas pendinginan (Qevap) Low stage fungsi dari beban pendinginan dan kecepatan putar kompresor low stage. Grafik tersebut memiliki trend line yang mengalami kenaikan secara linear seiring bertambahnya beban pendinginan dan kecepatan putar kompresor, dimana hal tersebut dikarenakan semakin meningkatnya beban pendinginan, maka temperatur evaporator akan semakin meningkat, hal ini mengakibatkan temperatur keluaran evaporator juga akan semakin meningkat, karena sistem pendinginan menggunakan katup ekspansi TXV makan aliran refrigeran akan semakin bertambah sehingga meningkatkan kapasitas pendinginan yang memiliki persamaan sebagai berikut.

$\mathrm{Q}$ _e $=\mathrm{m}$ _(ref_LS) (h_1-h_4)

Hal yang sama juga terjadi pada kenaikan kecepatan putar kompresor, dimana semakin meningkatnya kecepatan putar kompresor, maka aliran refrigeran juga semakin meningkat sesuai dengan Gambar 4.3. berdasarkan teori diatas maka gambar grafik hasil penelitian telah sesuai.

5) $\mathrm{COP}$

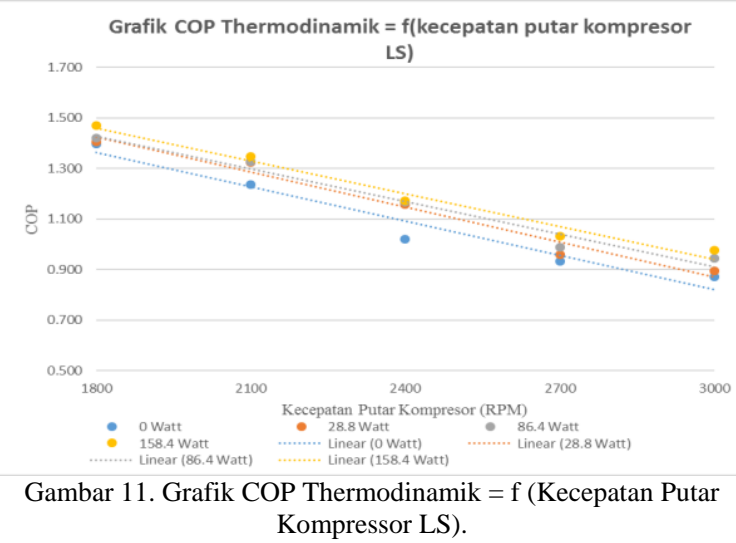

Gambar di atas menunjukan grafik COP dan temperature kabin terhadap pengaruh perubahan kecepatan kompresor low stage dan pengaruh beban pendinginan. Dari gambar grafik di atas, trend line grafik mengalami penurunan seiring dengan meningkatnya kecepatan putar kompresor dan berkurangnya beban (electric heater) yang terpasang pada kabin (cooling box). Dimana nilai laju COP terendah pada saat beban heater minimum (0 Watt) dan kecepatan putar kompresor maksimum (3000 rpm), dan tertinggi pada saat beban heater maksimum (158.4 Watt) dan kecepatan putar kompresor minimum (1800 rpm).

COP merupakan istilah efisiensi yang biasa digunakan pada sistem pendingin. Cara menghitungnya adalah dengan membagi kapasitas pendinginan yang didapat dengan nilai kerja kompresi. Sementara itu Sistem Refrigerasi Cascade menggunakan dua buah kompresor untuk menjalankan sistemnya, maka persamaannya akan berubah menjadi kapasitas evaporator sistem Low stage dibagi dengan penjumlahan nilai kerja kompresi pada masing-masing sistem seperti persamaan berikut:

$$
C O P_{\text {Thermo }}=\frac{\dot{Q}_{e_{-} L S}}{W_{\text {ref_HS }}+W_{\text {ref_LS }}}
$$

Semakin besarnya nilai COP seiring dengan bertambahnya nilai beban dikarenakan nilai kapasitas pendinginan semakin besar namun nilai kerja kompresinya tetap pada nilai yang cenderung konstan. Selain itu COP juga berpengaruh terhadap kecepatan putar kompresor karena semakin lambat kecepatan putar kompresor maka daya kompresor akan semakin kecil pula.

6) Menentukan kecepatan putar kompresor yang sesuai dengan beban pendinginan.

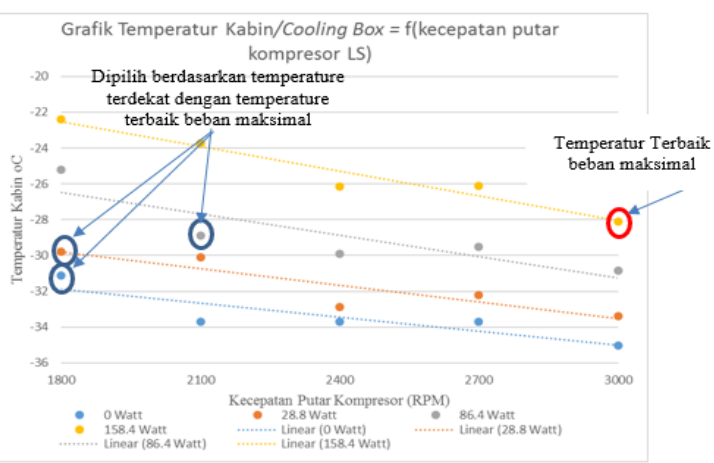

Gambar 12. Pemilihan Kecepatan Putar Kompresor Yang paling Sesuai Dengan Beban Pendinginan.

Penentuan kecepatan kompresor juga harus memperhatikan temperatur kabin yang menjadi tujuan sistem cascade untuk mendapatkan temperature sangat dingin. Sehingga dari Gambar 4.15 di tentukan limit nilai temperature kabin terendah ketika di berikan beban paling besar yaitu 158.4 Watt, dengan temperature kabin sebesar $-28.1{ }^{\circ} \mathrm{C}$ dimana kecepatan putar kompresor 3000 rpm $(50 \mathrm{~Hz})$. Selanjutnya dapat ditentukan kecepatan putar kompresor pada masing-masing beban dengan memperhatikan suhu kabin yang paling sedikit dibawah temperature $-28.1{ }^{\circ} \mathrm{C}$, sehingga didapatkan kecepatan putar kompresor yang sesuai dengan beban pendinginan sebagai berikut:

TABEL 1. HASIL ANALISA KECEPATAN PUTAR KOMPRESOR TERHADAP BEBAN PENDINGINAN

\begin{tabular}{|c|r|r|r|r|r|r|}
\hline Beban & $\mathrm{N}$ & $\begin{array}{c}\text { temperatu } \\
\mathrm{rkabin}\end{array}$ & $\begin{array}{c}\text { Kerja } \\
\text { Kompresi }\end{array}$ & $\begin{array}{c}\text { Konsumsi } \\
\text { listrik }\end{array}$ & $\begin{array}{c}\text { COP } \\
\text { Thermo }\end{array}$ & $\begin{array}{c}\text { COP } \\
\text { elektrik }\end{array}$ \\
\hline Watt & \multicolumn{1}{c|}{$\mathrm{rpm}$} & \multicolumn{1}{c|}{$\mathrm{oC}$} & \multicolumn{1}{c|}{$\mathrm{kW}$} & \multicolumn{1}{c|}{$\mathrm{kW}$} & & \\
\hline 0 & 1800 & -31.12 & 0.2595 & 0.5208 & 1.397 & 0.6962 \\
\hline 28.8 & 1800 & -29.78 & 0.2739 & 0.551 & 1.405 & 0.6986 \\
\hline 86.4 & 2100 & -28.88 & 0.3178 & 0.625 & 1.327 & 0.6749 \\
\hline 158.4 & 3000 & -28.1 & 0.5293 & 0.756 & 1.032 & 0.683 \\
\hline
\end{tabular}




\section{KESIMPULAN/RINGKASAN}

Hasil dari pengujian Sistem Refrigerasi Cascade dan pengolahan data yang telah dilakukan, maka penulis memperoleh beberapa kesimpulan sebagai berikut:

Pada pengujian didapatkan laju aliran massa yang semakin besar seiring dengan kenaikan putaran motor kompresor dan beban pendinginan, Dimana nilai laju aliran masa tertinggi sebesar $0.0027 \frac{\mathrm{kg}}{\mathrm{s}}$ (Beban 158.4 Watt dan $\mathrm{N}=3000 \mathrm{rpm}$ ). Nilai COP cenderung menurun seiring meningkatnya kecepatan putar kompresor dan mengalami peningkatan seiring bertambahnya beban pendinginan. Dimana COP tertinggi sebesar 1.471 (Beban 158.4 Watt dan $\mathrm{N}=1800$ rpm).Temperatur kabin cenderung menurun seiring meningkatnya kecepatan putar kompresor dan mengalami peningkatan seiring bertambahnya beban pendinginan. Dimana temperature kabin terendah sebesar -35.04 oC (Beban 0 Watt dan $\mathrm{N}=$ $3000 \mathrm{rpm}$ ). Sistem Cascade mengalami peningkatan kerja kompresi baik pada sisi low stage maupun sisi high stage seiring peningkatan beban pendinginan dan kecepatan putar kompresor. Nilai HRR (Heat Rejection Ratio) mengalami peningkatan kerja kompresi baik pada sisi low stage maupun sisi high stage seiring berkurangnya beban pendinginan dan meningkatnya kecepatan putar kompresor. Bedarsarkan hasil analisa maka didapatkan kecepatan putar kompresor yang paling sesuai berdasarkan beban pendinginan yang diberikan, terlihat pada tabel 1 .

\section{NOMENKLATUR}

Ui $\quad=$ Overall Heat Coefficient, ${ }^{W} / m^{2} K$

$A i \quad=$ Luas sisi-sisi kabin, $m^{2}$

Wref_HS = Kerja nyata kompresor untuk High Stage, Kw

Wref_LS = Kerja nyata kompresor untuk Low Stage, $\mathrm{kW}$
mref_HS = Laju aliran massa refrigeran Musicool-22, $\mathrm{kg} / \mathrm{s}$

miref_LS = Laju aliran massa refrigeran R404A, kg/s

Qe_HS = Panas yang diserap evaporator High

Stage, $\mathrm{kW}$

Qc_LS = Panas yang dilepaskan kondensor Low Stage, $\mathrm{kW}$

$h 1=$ Entalpi refrigeran masuk kompresor di

Low Stage, $\mathrm{kJ} / \mathrm{kg}$

h2 = Entalpi refrigeran masuk kondensor Low Stage, $\mathrm{kJ} / \mathrm{kg}$

h3 = Entalpi refrigeran keluar kondensor Low Stage, $\mathrm{kJ} / \mathrm{kg}$

$h 4=$ Entalpi refrigeran masuk evaporator di Low Stage, $\mathrm{kJ} / \mathrm{kg}$

h5 = Entalpi refrigeran keluar evaporator High Stage, $\mathrm{kJ} / \mathrm{kg}$

h6 = Entalpi refrigeran keluar kompresor di

High Stage, $\mathrm{kJ} / \mathrm{kg}$

$\mathrm{h} 7 \quad=$ Entalpi refrigeran masuk kondensor High Stage, $\mathrm{kJ} / \mathrm{kg}$

h8 = Entalpi refrigeran masuk evaporator High Stage, $\mathrm{kJ} / \mathrm{kg}$

\section{DAFTAR PUSTAKA}

[1] Ruben Induran Pinnata, TA: Pengujian Karakteristik Kerja Pada Sisi Low Stage Sistem Refrigerasi Cascade Dengan Fluida Kerja $R-407 F$ Sebagai Alternatif Ramah Lingkungan Dari R-404A Dengan Variasi Beban Pendinginan.Juli, 2015

[2] Windy Hernawan Mitrakusuma, Windy. 2009 Bahan Ajar Dasar Refrigerasi. Bandung: Polban, 2009.

[3] Michael J Moran, Shapiro, Howard N. Fundamentals of Enginering Thermodynamics, 5th. US : John \& Wiley Inc. 2006.

[4] Wilbert Stoecker, F. Jones, Jerold W. Refrigeration and Air Conditioning, 2nd Edition. Jakarta : Erlangga. 1987. 